
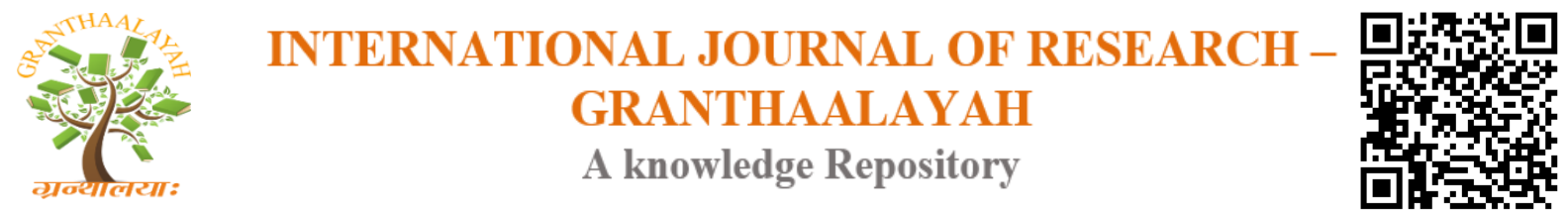

Science

\title{
ANALYSIS OF PROPERTIES OF CONCRETE USING SHEEP WOOL DIPPING IN SALT WATER AS FIBRE REINFORCEMENT ADMIXTURE
}

\author{
Vishal Gadgihalli ${ }^{* 1}$, MeenaY.R ${ }^{2}$, Chandana ${ }^{1}$, Raghavendra Prasad Havanje Dinakar ${ }^{3}$ \\ ${ }^{* 1}$ UG Student, Department Of Civil Engineering, Jain University, Bangalore, India \\ ${ }^{2}$ Assistant Professor, Department Of Civil Engineering, Jain University, Bangalore, India \\ ${ }^{3}$ Research Assistant, Department Of Civil Engineering, Jain University, Bangalore, India
}

\begin{abstract}
The use of admixtures is increasing very rapidly because concrete admixtures provide physical as well as economic benefits. These admixtures materials ranged from blood in history to recent fiber reinforcement. In this paper analysis of properties of concrete using salt water cored and oven dried sheep wool as fiber reinforced admixture was studied and verified the strength of concrete compared to ordinary Portland cements strength of different grade of concrete using sheep wool as fiber reinforcement admixtures. Using sheep wool as fiber reinforcement as concrete admixture gave good percentage of increment in both compressive strength and flexural strength of concrete, but as the grade of cement increases the percentage of increment in strength gradually reduces.
\end{abstract}

Keywords: Sheep Wool Admixture; Compressive Strength; Flexural Strength; Grade of Concrete.

Cite This Article: Vishal Gadgihalli, MeenaY.R, Chandana, and Raghavendra Prasad Havanje Dinakar. (2017). "ANALYSIS OF PROPERTIES OF CONCRETE USING SHEEP WOOL DIPPING IN SALT WATER AS FIBRE REINFORCEMENT ADMIXTURE." International Journal of Research - Granthaalayah, 5(11), 57-59. 10.29121/granthaalayah.v5.i11.2017.2328.

\section{Introduction}

The sheep is a quadropedal, ruminant mammal typically kept as livestock. Numbering a little over one billion, domestic sheep are also the most numerous species of sheep. Sheep are raised for fleece, meat and milk. A sheep's wool is the widely used animal fiber, and is usually harvested by shearing. Wool has several qualities that distinguish it from hair or fur: it is crimped and elastic [1]. Wool is produced by follicles which are small cells located in the skin.

Medullated fibers are nerve fibers which share nearly identical characteristics to hair and are long but lack crimp and elasticity. Kemp fibers are very coarse and shed out [2]. Wool fibers readily absorb moisture, but are not hallow. Wool can absorb almost one third of its weight of water [3]. Wool ignites at a higher temperature than cotton and same synthetic fibers. It has a 
lower rate of flame spread, a lower rate of heat release, a lower heat of combustion and does not melt or dip [4].

Although sheep wool can't be kept smooth while dipping in salt water is a best property which means that the surface tension of hair increases by dipping sheep wool in salt water, hence gives greater bond strength as author used the wool as fiber reinforced admixture. As it is oven dried these will be less chance of bio-degradation [5].

Dipping wool in acetone solution which removes impurities, but the present study author says, use of acetone for washing wool induces smoothening of dermis coat present on surface of wool, which results in lowering of bonding strength of admixtures. Acetone will smoothen the surface of wool hence reduces surface tension.

The author has experimented by dipping wool in salt water to increase its surface tension and bonding strength of admixtures to experience different results.

\section{Methodology}

The sheep wool were collected from different sources and they were dipped into salt water in the ratio of 35 grams per liter of water for 2days to make hair surface rough and it helps in good bond strength with concrete. The soaked wool is kept for drying under sunlight for one day. The hairs have been oven dried for 2 to 3 hours before mixing it into concrete. This oven drying helps in removal of water and helps in non-biodegradation of hair. Target strength of concrete was determined by the equation.

Target strength $=\mathrm{f}^{\prime} \mathrm{ck}=\mathrm{fck}+1.65(\mathrm{~s})$ - [eq1] according to standard code IS10262-2009. The amount of wool admixture was calculated from the following equation,

Volume of wool $=($ mass of chemical admixture/specific gravity of admixture $* 1000)$--- [2].

The specific gravity of sheep wool varies from 0.34 to 1.92 . The specific gravity of wool 2.21 was considered in this study. The compression and flexure strength were tested for 1, 7,14,21,28 days after casting.

\section{Results and Discussions}

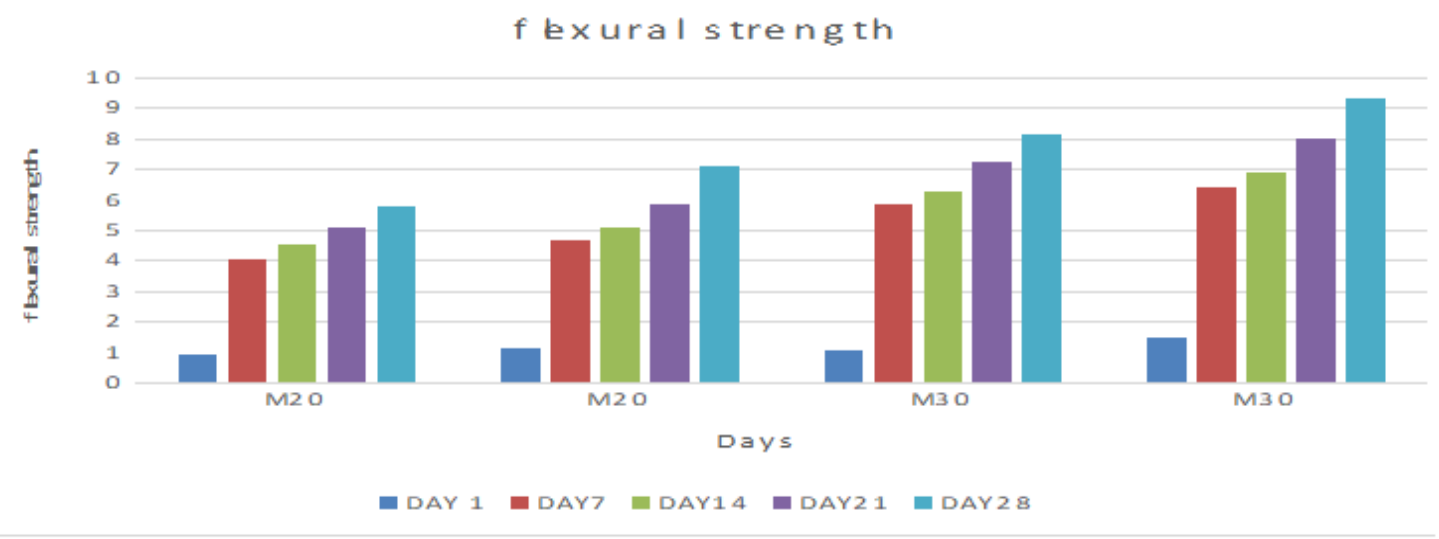




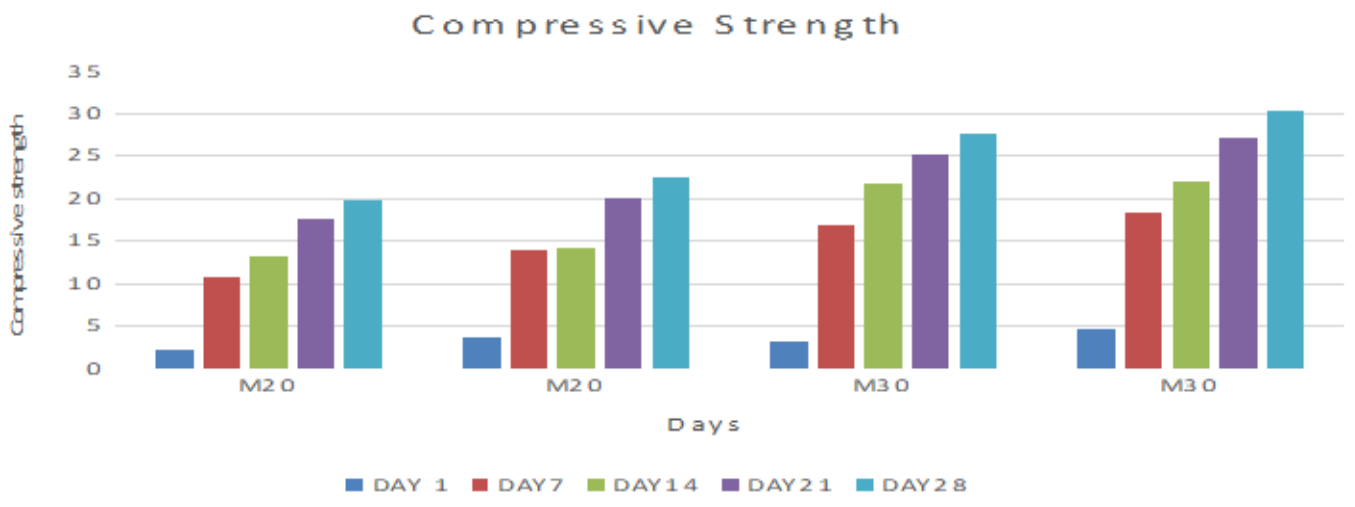

\section{Conclusions \& Recommendations}

From fig (1) it can be observed that M20 and M30 grade concrete with wool as fiber reinforced shows compressive strength of $22.43 \mathrm{MPa}$ and $30.29 \mathrm{MPa}$ respectively for 28 days, compared to normal concrete with 19.71 and $27.72 \mathrm{MPa}$. This shows approximately $12 \%$ and $8 \%$ increment in compressive strength. From fig[2] shows flexural strength of $7.11 \mathrm{MPa}$ and $9.36 \mathrm{MPa}$ for M20 and M30 grade for sheep fiber reinforcement concrete for 28 days, compared to normal concrete of $5.58 \mathrm{Mpa}$ and $8.17 \mathrm{MPa}$ respectively, showing approximately $19 \%$ and $13 \%$ increment in flexural strength by M20 and M30 grade of concrete.

By using wool dipped in salt water as an admixture, withstands more compressive and flexural strength than ordinary Portland cement.

\section{Acknowledgements}

Special thanks for Hithesh Nagothu, Megha.R for helping me in completing this work successfully. And I also thank my parents, teachers, friends and all elders who supported me.

\section{References}

[1] DArcy N.B. sheep and wool technology, NSW university press, kensing ton, 1986 USBN 086840-106-4.

[2] Simmons, paula (2009). Storey's Guide to Raising sheep. North Adams, MA; storey publishing. Pp.315-316.

[3] Wool facts. Aussies sheep and wool.com.au. Retrieved on 2012-08-05.

[4] Wool History. Tricountyfarm.org. Retrieved on 2012-08-05.

[5] Jain D. and Kothari A.: Hair fiber reinforced concrete 2012.

*Corresponding author.

E-mail address: g.vishal1912@ gmail.com 